\title{
STABILITY AND TOXICITY TEST OF ANGKAK PIGMENT POWDER FROM SAGO HAMPAS- RICE FLOUR SUBSTRATE AS NATURAL DYES
}

\author{
Dian Pramana Putra ${ }^{1}$, Novelina $^{2}$, Alfi Asben*,2 \\ ${ }^{1}$ Faculty of Agricultural, Ekasakti University, Padang, Indonesia \\ ${ }^{2}$ Faculty of Agricultural Technology, Andalas University, Padang, Indonesia \\ *Coresponden author \\ Email: alfi_asben@yahoo.com
}

\begin{abstract}
Sago hampas is waste from processing sago starch. Sago hampas is generally thrown away without any further treatment. Sago hampas contain nutrients that can be used as a substrate for fermentation of angkak. The study aims to determine the stability and toxicity of angkak pigment powder from sago hampas-rice flour substrate. The study used exploratory research design through experiments in the laboratory. This study used the UV-vis spectrophotometer method in observing the stability of the Angkak powder pigment and the brine shrimps method of angkak pigment powder toxicity test. The results showed that the level of solubility of angkak pigment powder will increase at higher temperatures. Stability of angkak pigment powder tends to decrease with longer heating, the higher of heating temperature and the longer of irradiation. Angkak pigment powder are more stable at neutral and alkaline $p H$ compared with acidic $p H$. And it is not toxic to experimental animals with $L C_{50}$ value of angkak pigment powder of 2,897.05 ppm. The conclusion of this study is that temperature affects the intensity of the angkak pigment. Angkak is unstable along with heating time, heating temperature and longer of irradiation.
\end{abstract}

Keywords: monascus purpureus; angkak pigment powder; pigment stability; pigment toxicity

\section{Introduction}

Sago hampas is one of the agricultural industrial wastes whose utilization is still not well managed. Sago hampas can be used as a fermentation substrate in making Angkak. According to Asben (2012) the percentage of the main ingredients of sago hampas are hemicellulose 14\%, cellulose $21 \%$, fat $2 \%$, crude protein $1 \%$, lignin $6 \%$, starch $51 \%$, and others $5 \%$. Therefore sago hampas can be used as angkak pigment fermentation substrate because it contains carbon, nitrogen and minerals needed by microbes as nutrients during the fermentation process. Angkak is a fermented product by the Monascus purpureus. Monascus is known to be an important fungus in producing red pigment. The pigment produced by $M$. purpureus is very stable and safe to use as a food additive. Monascus purpureus has been widely used to produce pigments through fermentation processes both on solid substrates and on liquid substrates (Sheu et al. 2000 in Yuliani, 2014).

Angkak is generally made using rice as a fermentation substrate. For this reason, it is necessary to use other ingredients as angkak pigment substrate, one of which is sago hampas. Research on the use of sago hampas as a fermentation substrate has been carried out by Asben and Kasim (2015) and Asben et al. (2017), but no extraction of the sago residue pigment was carried out. Generally Angkak which is sold in the market is still in solid form which is the result of 
fermentation and is still mixed with the fungi of Monascus itself. So that its use will affect the consistency of the product to be dyed. It is necessary to separate the Angkak pigment from the fermentation substrate such as the research of Putra et al. (2018) which extracts the Angkak pigment from the sago hampas substrate. Angkak has a consistent color but is less stable to physical and chemical influences such as heat, UV-rays and sunlight, can mix with other natural dyes with food ingredients, non-toxic and not a carcinogen (Hesseltine, 1965 and Stainkraus, 1983 in Jenie et al., 1994). According to Triana and Nurhidayat (2009), angkak pigments are also not carcinogenic, besides the presence of lovastatin in angak can reduce cholesterol and triglycerides. It is necessary to study the stability and toxicity of angkak pigment powder before applying it to food.

Research related to the pigment stability of Angkak has been carried out by several researchers, such as Priatni (2015) who conducted research on encapsulation studies and pigment stability from fermented rice extracts. Jenie et al. (1997) conducted a study on the production of Angkak Concentrate and Pigment Powder from Monascus purpureus and its stability during storage. Furthermore Kaur et al. (2009) conducted a study of production and evaluation of the physicochemical properties of red pigment from Monascus purpureus MTCC 410.

In a study conducted by Putra et al. (2018), in fermentation of Angkak sago hampas produced Angkak pigment powder. In this study, Angkak pigments were extracted using an ultrasonic bath with a long extraction time as a treatment. in his research there was no test on the stability of the resulting Angkak pigments. This study aims to determine the stability of angkak pigment powder from physical and chemical influences and determine the toxicity of angkak pigment powder produced.

\section{Methods}

\subsection{Materials}

The raw material used in the form of angkak pigment powder obtained from the extraction of angkak powder from sago hampas and rice flour. Chemicals used include distilled water, methanol, DMSO, buffered citrate $\mathrm{pH}$ 3, 4 and 5, buffered phosphate $\mathrm{pH}$ 6, 7 and 8 and carbonate $\mathrm{Na}$ pH 9 and others. Experimental animals namely Artemian salina Leach shrimp larvae.

The tools used are pH meter (Delta OHM HD 2105.2, Italy), spectrophotometer (Shimadzu UV-1800), cabinet dryer (Corsiar Manufacturing), ovens (Philip Harris Ltd and Memmert), analytical scales (Kern ABJ 220-4M), lamps incandescent 20 watts, aquariums, water pumps, glassware such as goblets, test tubes and others.

\subsection{Experimental Design}

The design in this study is based on research by Putra et al. (2018) with differences in the extraction time of Angkak pigments. Furthermore, the best results from his research were 
continued with testing the stability of the Angkak pigment. The research design used was explorative research methods through experiments in the laboratory. Data was collected by direct observation after the research object was given treatment, then conducted a series of tests.

\subsection{Experiments}

Preparation and refreshment of M. purpureus and preparation of sago hampas (Asben \& Kasim, 2015)

Sago hampas is dried up to $10 \%$ moisture content and size is reduced by using a blender then filtered with a sieve to obtain 40-60 mesh size. sago hampas is ready to be used as a fermentation substrate. The pure culture of M. purpureus is refreshed on the agar sloping PDA media. Incubated at room temperature for 21 days. Ascospores / conidia are released on the sloping surface by giving $5 \mathrm{~mL}$ of sterile distilled water. Continue to be crushed with the ose so that the askospora is released and is suspended in aquades. The number of spores is calculated with a heamocytometer. Culture is ready to use.

\section{Angkak pigmen production from sago hampas-rice flour substrat (Asben \& Kasim, 2015)}

Fermentation uses a mixture of sago hampas with a particle size of 40-60 mesh and rice flour with a ratio of sago hampas : rice flour $(1: 1)$ in a sterile erlenmeyer. Next added $2.5 \%$ glucose solution to $\pm 50 \%$ substrate water content. Sterilization with an autoclave of $121^{\circ} \mathrm{C}$ for 20 minutes. Substrate is allowed to cool in laminar air flow, then put inoculum as much as $10 \%$ of the total substrate, the substrate is stirred until homogeneous. Then incubated at room temperature 28-30 ${ }^{\circ} \mathrm{C}$ for 14 days. Then the fermentation results are dried for 72 hours at $40-45{ }^{\circ} \mathrm{C}$ until the water content of the powder becomes $\pm 7 \%$. Angkak crushed and filtered using a 100 mesh size sieve, then extraction and observation were carried out.

\section{Angkak pigmen extraction and encapsulation (Putra et al. 2018)}

Angkak pigment extraction process is carried out by following the procedure as follows. Angkak that has been prepared previously and added $60 \%$ ethanol with a ratio of 1:10. Furthermore, it was extracted using an ultrasonic bath according to the extraction time 40 minutes. The extraction results were filtered with Whatman paper No 1. Then the resulting filtrate was evaporated using a rotary vacuum evaporator solvent until the pigment angkak extract was obtained. The extract is then encapsulated. The encapsulation process is carried out using maltodextrin as a filler with a concentration of $10 \%$. Angkak pigment extract was added to the maltodextrin solution, then homogenized and dried using a freeze dryer until the water content reached $\pm 5 \%$. Furthermore, an analysis of angkak pigment powder was carried out.

\subsection{Analysis}

Observations made on the encapsulated red yeast rice extracted include: Test the solubility of red yeast rice pigment powder, Test the effect of temperature, $\mathrm{pH}$, heating time and exposure 
time on the stability of the pigment powder (Jenie et al., 1997); and the toxicity test of Angkak Pigment Powder according to the Brine Shrimps method (Hernindya et al., 2014).

\section{Results and Discussion}

\subsection{Solubility of Angkak pigment powder}

This test was conducted on the best product from the research of the extraction time of angkak pigments and the types of solvents used in the extraction of angkak pigments. The results of the analysis on the ease of solubility of angkak pigment powder can be seen in Figure 1.

The solubility test of Angkak pigment powder is done by dissolving Angkak pigment powder in water with several different temperatures. Angkak pigment powder solubility test needs to be done to determine the solubility level of red angkak pigment in water. Increased color intensity of Angkak pigments due to differences in water temperature occurs in all types of pigments. The absorbance value of red pigment increased asorbansi from 0.728 to 0.865 .

Based on the graph above it is known that an increase in temperature will increase the intensity of the yellow, orange and red pigments in Angkak pigment powder. Thus, it can be seen that the pigment is more soluble at high temperatures. This happens because of the kinetic energy from heat. According to Jenie et al., (1994), the kinetic energy that occurs due to heating at high temperatures can cause the pigment to decompose faster and dissolve in water.

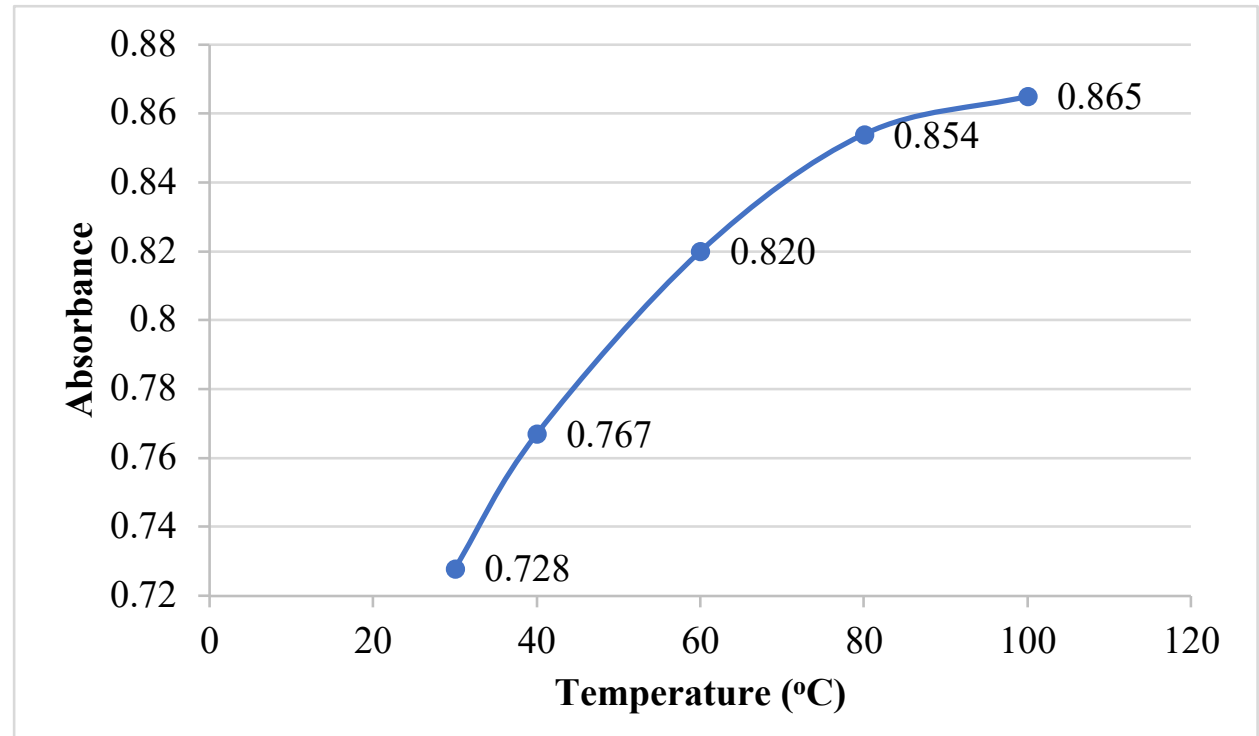

Figure 1. Graph of solubility of Angkak pigment powder in water

The ease of Angkak pigment powder in cold water is caused by the use of maltodextrin as filler material in the encapsulation of Angkak pigment, one of the properties of maltodextrin is soluble in cold water. This is in accordance with the statements of Blanchard and Katz (1995), explaining further the properties possessed by maltodextrin such as experiencing rapid dispersion, having high solubility properties and forming films, forming low hygroscopic properties, low browning properties, able to inhibit crystallization and has a strong bond. 
The solubility value of Angkak pigments from this study was higher than the results of the research of Fatimah, Suprihadi and Kusdiyantini (2014) where the lowest solubility average of Monascus red pigment at $25^{\circ} \mathrm{C}$ was 0.28 while the highest solubility was at $100^{\circ} \mathrm{C}$ of 0.56 . according to Fatimah et al., (2014) Judging from the absorbance value obtained that the high temperature is $100^{\circ} \mathrm{C}$, fermentation powder has a color intensity that tends to be high compared to low temperature, this shows that the color stability is influenced by temperature. this is in accordance with the research results that have been obtained.

\subsection{Effect of Temperature on the Stability of Angkak Pigment Powder}

The stability test of Angkak pigment powder towards temperature aims to determine the level of stability of pigment at high temperatures. This test uses different temperature levels, i.e.: $50^{\circ} \mathrm{C}, 100^{\circ} \mathrm{C}, 150^{\circ} \mathrm{C}$ and $200^{\circ} \mathrm{C}$, and as a comparison is the initial pigment without heat treatment. The results of the analysis of the effect of temperature on the stability of Angkak pigment powder can be seen in Figure 2.

The results of the analysis showed a decrease in the intensity of angkak pigment as the temperature increased. The intensity of the red pigment color in angkak pigment powder absorbance values ranged from 0.307 to 0.886 for the best treatment of the type of solvent, namely methanol solvent. The angkak pigment intensity at the beginning (without heat treatment) by giving $50^{\circ} \mathrm{C}$ heat only slightly decreased the intensity of pigment. But after the heating temperature reached $100^{\circ} \mathrm{C}$, the intensity of angkak pigment showed a significant decrease until the temperature of $200^{\circ} \mathrm{C}$.

The results of the analysis of the stability of Angkak pigment powder on different heating temperatures showed that there was a decrease in the intensity of Angkak pigment powder. Storage of Angkak pigment powder at room temperature of $26^{\circ} \mathrm{C}$ for 1 hour does not cause changes in the absorbance value of Angkak pigment, nor in heating at temperature $100^{\circ} \mathrm{C}$ Angkak pigment color is still relatively stable, only slightly changes the absorbance value of Angkak pigment color. After storage at $150^{\circ} \mathrm{C}$ for 1 hour there was a very significant change. This change in the form of a decrease in the absorbance value of angkak pigment powder to a paler color. Similarly, heating at $200^{\circ} \mathrm{C}$ the intensity of angkak pigments decreases marked by the paler color produced.

This happens because at temperatures above $100^{\circ} \mathrm{C}$, the red pigments, monascorubramin and rubropunctamin, tend to become unstable due to heating. Reduction in red pigment color due to heating due to red pigment damage to the pigment chromophore group. The damage is caused by the release of functional groups or opening of functional groups that make up the red pigment chromophore group. So there is a decrease in the intensity of red pigment along with an increase in heating temperature (Asadayanti et al., 2010). Santoni, Darwis and Syahri (2013), added that the main cause of the increasing of the heating temperature, the less the color intensity of the 
anthocyanin extract solution, this is due to the degradation of the anthocyanin. Anthocyanin degradation can be in the form of breaking of glycosidic bonds which causes unstable anthocyanidins and changes in the structure of anthocyanidins to chalcone compounds.

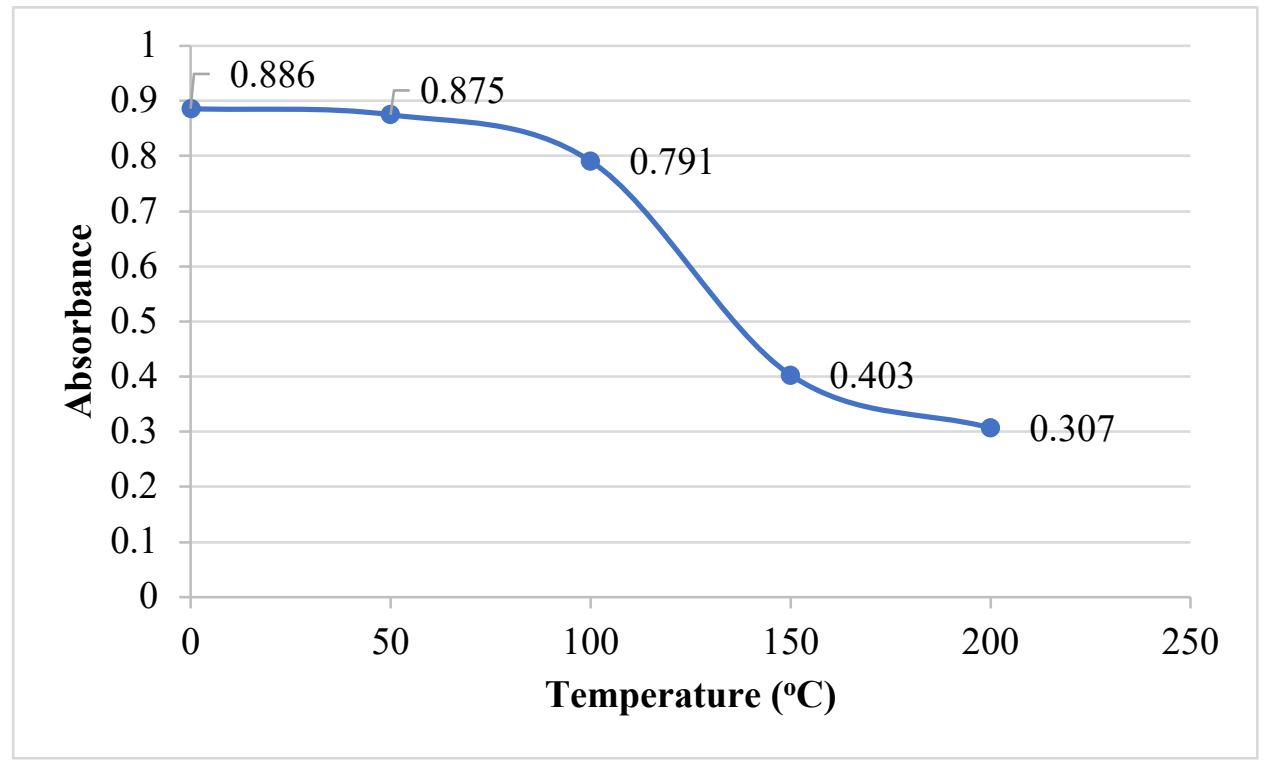

Figure 2. Graph of pigment stability at different heating temperatures

This is in accordance with the statement of Tedjautama and Zubaidah (2014) the results of the red pigment stability test against temperature showed a decrease in the intensity of the red pigment after being incubated at a certain temperature for 1 hour. Angkak pigment stability decreased at temperatures of $121^{\circ} \mathrm{C}$ and $180^{\circ} \mathrm{C}$. It is suspected that the pigment was damaged due to heat. According to Priatni (2015) monascus fermented rice pigment stable to at temperature $50^{\circ} \mathrm{C}$ for 30 minutes.

\subsection{Effect of pH on Angkak Powder Solution}

Angkak pigment powder stability testing at different $\mathrm{pH}$ conditions was carried out by dissolving Angkak pigment powder in a solution with a $\mathrm{pH}$ condition of 3-9. Stability testing is carried out for 6 hours where every 3 hours an analysis is performed. The results of the analysis on the effect of different $\mathrm{pH}$ on the stability of Angkak pigment powder can be seen in Figure 3 .

The analysis showed an increase in the intensity of angkak pigment along with the increase in the $\mathrm{pH}$ value of the solution. Red pigment intensity, namely monascorubramin and rubropunctamin on angkak powder ranged from 0.075 to 0.155 with 3 hours of coding and 0.052 to 0.140 with 6 hours of conditioning for the best treatment of the type of solvent, namely methanol solvent.

The results of the analysis of the influence of $\mathrm{pH}$ on the stability of Angkak powder pigments showed that there was a change in the absorbance value at each difference in the $\mathrm{pH}$ value. In acidic atmosphere, the Angkak powder pigment stability is lower than neutral and basic atmosphere. According to Fabre et al., (1993) red pigments are most sensitive to acidic $\mathrm{pH}$ and are 
more stable under alkaline conditions. Radiastuti (2005) research results, also reported the same results that angkak pigments are less stable in acidic conditions and more stable in neutral or basic conditions. The color stability of pigments produced by microorganisms including fungi is generally more stable to heat, light and $\mathrm{pH}$ compared to pigments from plants (Malik et al., 2012). However, pigments from microbes are unstable at too acidic $\mathrm{pH}$ and high temperatures. Carvalho et al. (2005), in the analysis of the stability of the red biopigment produced by Monascus fungi on the treatment of $\mathrm{pH}$ and temperature reported that biopigment treatment at $\mathrm{pH} 4-8$ obtained information that the smaller the $\mathrm{pH}$, the more significant the pigment damage was. This red pigment from Monascus is stable at $\mathrm{pH} 7$.

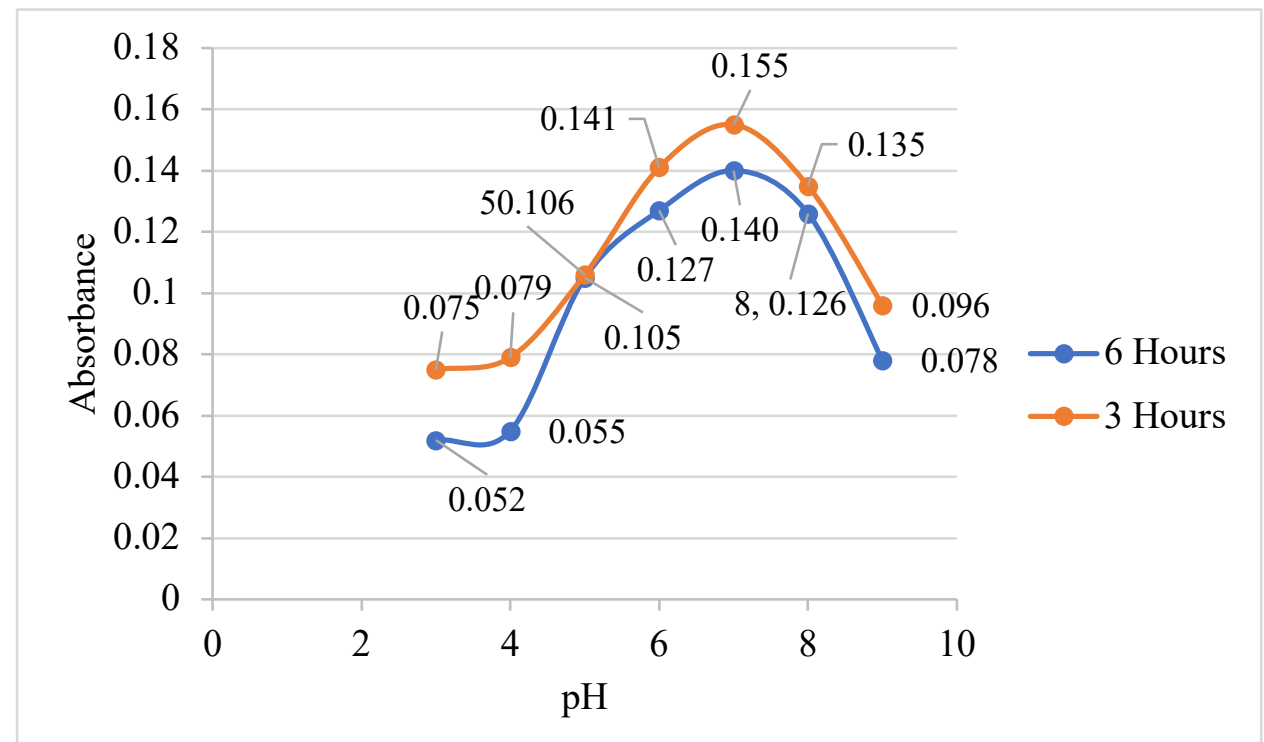

Figure 3. Graph of pigment stability at different $\mathrm{pH}$

Natural pigments that are sensitive to acidic $\mathrm{pH}$ are present in the form of flavilium cations which are red in color and lack of electrons. With increasing $\mathrm{pH}$ the flavilium cation group gets an electron donor and turns into a colorless chalcone. This is indicated by a decrease in absorbance in sample testing (Jenie et al., 1997). According to Radiastuti (2005), the mechanism of damage to angkak pigments due to changes in $\mathrm{pH}$ is unclear, but it can be suspected that the damage also occurs due to changes in donor or electron acceptor in the cation group, causing the structure of the compound to change.

The results of Tedjautama and Zubaidah (2014) research on the stability of the red pigment against $\mathrm{pH}$ show that the red pigment is more stable at neutral $\mathrm{pH}(\mathrm{pH} 7)$ than at acidic $\mathrm{pH}(\mathrm{pH} 3)$. this is in accordance with the results of the research that has been done. at acidic $\mathrm{pH}$ the stability of the pigment in Angkak decreased. It is thought that the pigment has been damaged by the $\mathrm{H}^{+}$ ions in the acid. According to Priatni (2015) stability of MFR pigment was decreased under acidic conditions and stable at at $\mathrm{pH}$ value 5-6. Kaur et al. (2009) Angkak pigment stability is stable at pH 6-8 and more stable at neutral pH conditions. 


\subsection{Effect of Heating Time on the Stability of Angkak Pigment Powder}

Testing the stability of pigment powder Angkak pigment against heating time carried out for 3 hours using an oven with a temperature of $100^{\circ} \mathrm{C}$. Every hour the sample of pigment intensity was measured using a spectrophotometer. The results of the analysis of the effect of heating duration can be seen in Figure 4.

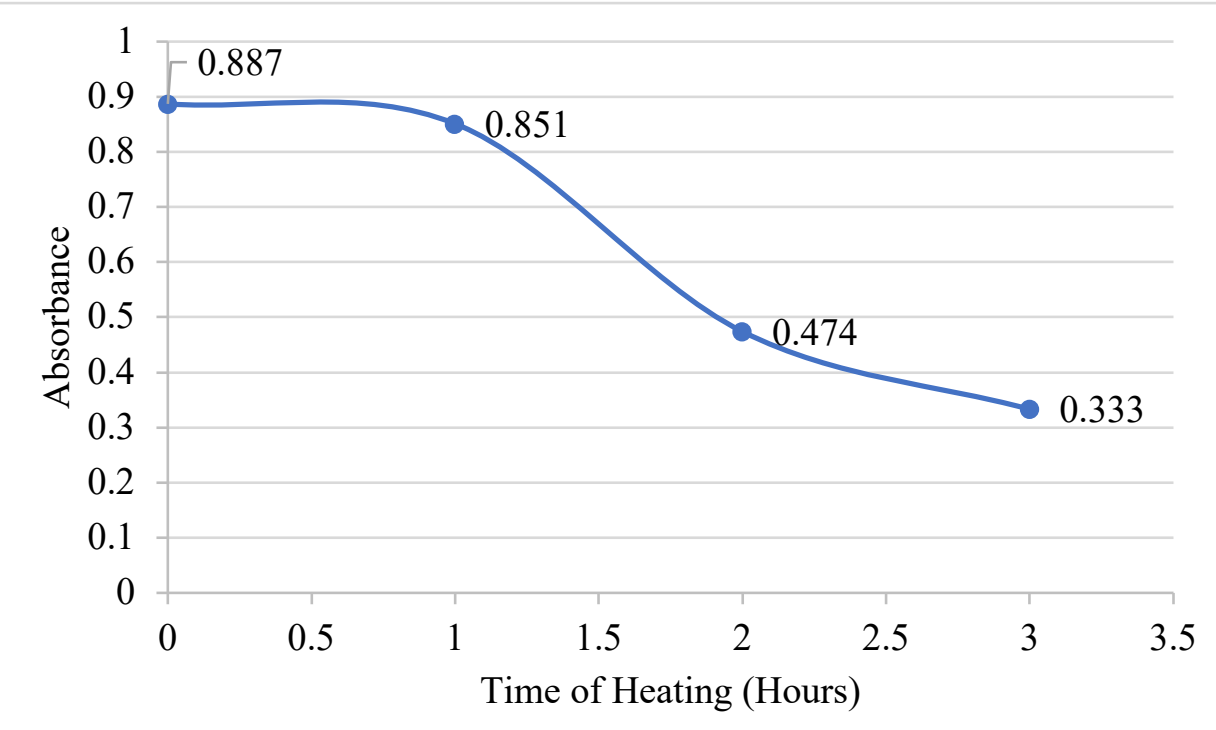

Figure 4. Graphic stability of pigment on heating time.

The analysis showed that Angkak pigment powder which was heated for 3 hours at $100^{\circ} \mathrm{C}$ showed a decrease in pigment intensity due to this treatment. The intensity of red pigment in angkak powder absorbance value ranges from $0.333-0.887$. The highest pigment intensity in the treatment without heating with an absorbance value of 0.887 but not different from the treatment with heating for one hour with an absorbance value of 0.851 . The decrease in color intensity of Angkak pigment powder is caused by damage to the chromophore group of the dyestuff, namely changes in bonding or functional groups. This occurs marked by a decrease in the absorbance value at every one hour heating for 3 hours. In addition, the effect of long heating in a long time will cause kinetic energy that is thought to be the cause of the damage. Damage to the chromophore group will cause the dyeing of the dye but if seen visually there is no significant change in color (Sutrisno, 1987). The results of research conducted by Radiastuti (2005) stated that Monacus pigment heated for 4 hours at $100^{\circ} \mathrm{C}$ showed a decrease in the intensity of the red pigment due to treatment.

\subsection{The Effect of Irradiation Time on the Stability of Angkak Pigment Powder}

Testing stability of Angkak pigment powder pigments against irradiation time is done by using Philips 40 watt incandescent lamp. Where the sample is conditioned in a closed container or box and given an incandescent lamp for 6 hours and every 3 hours analysis of angkak pigments is analyzed. The results of the analysis of the stability of pigment powder Angkak pigment against the long exposure can be seen in Figure 5. 


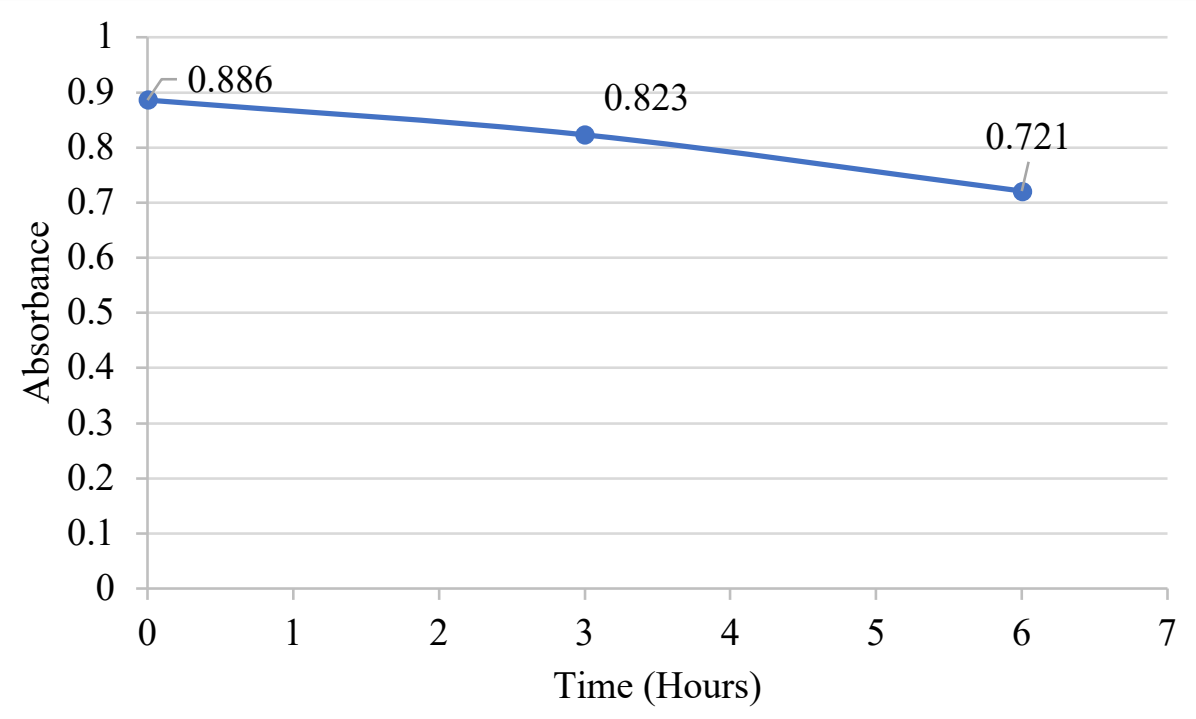

Figure 5. Graph of pigment stability at exposure time.

Based on the graph above the reduction in the intensity of angkak pigment along with the longer irradiation. The intensity of the red pigment in angkak powder absorbance value ranges from $0.721-0.886$. In the first 3 hours irradiation the absorbance value of the sample was 0.823 and not much different from the initial sample with an absorbance value of 0.886 , but after irradiation for 6 hours there was a considerable decrease with an absorbance value of 0.721 .

Based on the analysis of the effect of irradiation time it was found that the angkak pigment powder was relatively stable in irradiation for 3 hours, this was marked by a slight change in the absorbance value of the sample. But after irradiation for 6 hours has seen a decrease in the intensity value of angkak pigment powder which is marked by the decreasing value of the absorbance of the sample. This decrease in absorbance value is because during the irradiation process the temperature around the box increases to $45^{\circ} \mathrm{C}$, the longer the irradiation the longer the sample will be exposed to heat from the incandescent lamp used.

Light rays can affect the stability of angkak pigments, Smith (1975) states that source of light are emits energy and some of this energy is converted into visible light. This is reinforced by the opinion of Markakis (1982) that the pigment has a strong tendency to absorb visible light and the radiation energy of the light causes photochemical reactions in the visible spectrum and results in discoloration. Bilyk et al. (1981) conducted a study of the effect of light conditions on the stability of red beet pigments resulting in color loss of up to $50 \%-60 \%$. According to Kaur et al. (2009) Angkak pigments are stable during irradiation for up to 24 hours. Color reduction in angkak pigment occurs after irradiation for more than 24 hours.

\subsection{Brine Shrimps Method of Angkak Pigment Powder Toxicity Test}

The toxicity test of Angkak pigment powder uses the Brine Shrimps Lethality Test (BSLT) method, which is a screening method to determine the toxicity of a compound or extract of natural 
substances that are cytotoxically acutely by using experimental animals Artemia salina Leach larvae. To calculate the $\mathrm{LC}_{50}$ value, a curve that states the log concentration of the test extract that causes death of $50 \%$ A. salina larvae as the $\mathrm{x}$-axis, and mortality of A. salina $50 \%$ larvae after a 24-hour incubation period as the y-axis, is plotted in the linear regression equation $y=a+b x$. Using this formula, values $\mathrm{a}$ and $\mathrm{b}$ are obtained based on data from the 10 concentration points used. $\mathrm{LC}_{50}$ value is determined through probit analysis of the data obtained. Data on the results of the toxicity testing of angkak products against A. salina larvae can be seen in Table 1.

Table 1. Angkak toxicity against Artemia salina Larvae

\begin{tabular}{lc}
\hline Treatment & $\mathrm{LC}_{50}(\mathrm{ppm})$ \\
\hline Angkak pigment powder & 2897.05 \\
\hline Information: & \\
LC50 < 1000 ppm: Toxic \\
LC50 > 1000 ppm: Non toxic \\
Data obtained from the average results of each test
\end{tabular}

Toxicity test based on the Table 1 it is known that the toxicity value of Angkak pigment powder is $2,897.05 \mathrm{ppm}$. From the results of the toxicity analysis it can be concluded that the product of the Angkak Pigment Powder is not dangerous (toxic) to humans if applied to food products, because the value of $\mathrm{LC}_{50}$ is obtained more greater than $1000 \mathrm{ppm}$. An extract is declared to have acute toxicity if it has an $\mathrm{LC}_{50}$ value of less than $1000 \mu \mathrm{g} / \mathrm{mL}$. Lethal Concentration 50 $\left(\mathrm{LC}_{50}\right)$ is a concentration of substances that cause the death of $50 \%$ of experimental animals, namely larvae Artemia salina Leach (Rolliana, 2010).

Angkak pigment powder does not contain toxic compounds due to the process of extracting pigment from Angkak with methanol as a solvent. Furthermore, concentration of angkak pigment extract was carried out with a rotary vacum evaporator until no solvent was left. Furthermore, it is encapsulated using fillers that can be consumed and dried with a freeze dryer, so that the final results of Angkak pigment in powder form. According to Triana and Nurhidayat (2009), angkak pigments are also not carcinogenic, besides the presence of lovastatin in angkak can reduce cholesterol and triglycerides. Asben and Permata (2018) in their research the effect of sago hampas particle size in angkak pigmen production using Monascus purpureus, it was found that angkak's toxicity value was $1719.86 \mathrm{ppm}$ which indicates that angkak from sago pulp is not toxic.

\section{Conclusion}

The results showed that the pigment powder Angkak will increasingly dissolve at higher temperatures. Stability of angkak pigments tends to decrease with longer heating, the higher the heating temperature and the longer the irradiation. Angkak pigment powder is more stable at neutral and basic $\mathrm{pH}$ compared to acidic $\mathrm{pH}$. Angkak pigment residue pigment powder is not toxic to experimental animals with $\mathrm{LC}_{50}$ value (toxicity value) Angkak pigment powder of $2897.05 \mathrm{ppm}$. 


\section{References}

Asadayanti, D. D, Jenie, B. S. L., Kusumaningrum, H. D, \& Nurhidayat, N. (2010). Peningkatan Kadar Lovastatin Angkak oleh Monascus purpureus Ko-kultur dengan Endomycopsis burtonii. Jurnal Ilmu-Ilmu Hayati, 10(3), 313-321. https://doi.org/10.14203/beritabiologi.v10i3.746

Asben, A. (2012). Rekayasa Proses Produksi Hidrolisat Dari Ampas Sagu Sebagai Substrat Untuk Pembuatan Bioetanol (Doctoral dissertation). Retrieved from https://repository.ipb.ac.id/handle/123456789/58950

Asben, A. \& Kasim, A. (2015). Studi Lama Fermentasi dan Tingkat Kadar Air dalam Produksi Pigmen Angkak pada Substrat Ampas Sagu-Tepung Beras Menggunakan Monascus purpureus. Prosiding Seminar Agroindustri dan Lokakarya Nasional FKPT-TPI. Madura, Indonesia. 2-3 September 2015.

Asben, A \& Permata, D. A. (2018). Pengaruh Ukuran Partikel Ampas Sagu dalam Produksi Pigmen Angkak Menggunakan Monascus purpureus. Jurnal Teknologi Pertanian Andalas, 22(2), 111-117. https://doi.org/10.25077/jtpa.22.2.111-117.2018

Asben, A., Murtius, W. S \& Helmia, P. (2017). Studi Penentuan Perbandingan Ampas Sagu Terhadap Tepung Beras Untuk Produksi Pigmen Angak dari Monascus purpureus. Prosiding Seminar Nasional FKPT-TPI. Kendari, Indonesia. 20-21 September 2017.

Bilyk, A., Kolodij, M. A. \& Sapers, G. M. (1981). Stabilization of Red Beet Pigment with Isoascorbic Acid. Journal of Food Science 46(5), 1616 - 1617. https://doi.org/10.1111/j.1365-2621.1981.tb04233.x

Blanchard, P. H \& Katz, F. R. (1995). Starch Hydrolysates in Food Polysaccharides and Their Applications. New York, USA: Marcel Dekker, Inc.

Carvalho, J. C., Oishi, B. O., Pandey, A., \& Soccol, C. R. (2005). Biopigments from Monascus: Strain selection, citrinin production and color stability. Brazilian Archives of Biology and Technology, 48 (6), 885-894.

Fabre, C.E., A. L, Santerre., M. O, Loret and R. Baberian (1993). Production and food applications of the red pigments of Monascus ruber. Journal of Food Science, 58(5), 1099-1102. https://doi.org/10.1111/j.1365-2621.1993.tb06123.x

Fatimah, S., Suprihadi, A., \& Kusdiyantini, E. (2014). Produksi dan Kestabilan Pigmen Merah Kapang Monascus sp. Menggunakan Media Tepung Kulit Singkong dengan Penambahan Bekatul pada Konsentrasi yang Berbeda. Jurnal Akademika Biologi, 3(4), 49-59. https://ejournal3.undip.ac.id/index.php/biologi/article/view/19460

Hernindya, A., Swantara, M. D. \& Suaniti, N. M. (2014). Identifikasi dan Uji Toksisitas Ekstrak Etanol Spons Hyrtios erecta Terhadap Larva Udang Artemia salina L. Indonesia EJournal of Applied Chemistry, 2(1), 25-30.

Jenie, B. S. L., Helianti \& Fardiaz, S. (1994). Pemanfaatan Ampas Tahu, Onggok dan Dedak untuk Produksi Pigmen Merah oleh Monascus purpureus. Buletin Teknologi dan Industri Pangan, 5(2), 22-29.

Jenie, B. S. L., Mitrajanty, K. D \& Fardiaz, S. (1997). Produksi Konsentrat dan Bubuk Pigment Angkak Dari Monascus purpureus serta Stabilitasnya Selama Penyimpanan. Buletin Teknologi dan Industri Pangan, 8(2), 39-46.

Kaur, B, D, Chakraborty. \& K, Harbinder. (2009). Production and Evaluation of the physicochemical Properties of Red Pigment from Monascus purpureus MTCC 410. The Internet Journal of Microbiology TM, 7(1), 1-6. DOI: 10.5580/d4a

Malik, K., Tokkas, J. \& Goyal, S. (2012). Microbial Pigments : A review. International Journal of Microbial Resource Technology, 1(4), 361-365.

Markakis, P. (1982). Anthocyanins as Food Additives in P. Markakis, (ed) Anthocyanins as Food Colors. New York, USA: Academic Press.

Priatni, S. (2015). Encapsulation and Stability Study of Monascus Fermented Rice Extract. Procedia Chemistry, 17,189-193. DOI: 10.1016/j.proche.2015.12.118 
Putra, D. P., Asben, A. \& Novelina, N. (2018). Penentuan Waktu Ekstraksi Pigmen Angkak dari Substrat Ampas Sagu Menggunakan Ultrasonicbath. Jurnal Litbang Industri, 8(2), 83 - 88. http://dx.doi.org/10.24960/jli.v8i2.4094.83-88

Putra, D. P., Asben, A dan Novelina. (2018). Studi Ekstraksi dan Uji Karakterisasi Pigmen Angkak Dari Substrat Ampas Sagu (Metroxylon Sp) Sebagai Pewarna Alami (Master Thesis). Retrieved from http://scholar.unand.ac.id/37478/

Radiastuti, N. (2005). Produksi Pekatan dan Kristal Pigmen oleh Monascus purpureus TSTR 3090 Sebagai Pewarna Merah Alami Makanan dan Minuman serta Stabilitasnya Selama Penyimpanan. Jakarta, Indonesia: Lembaga Penelitian UIN Syarif Hidayatullah.

Rolliana, E. R. (2010). Uji Toksisitas Akut Ekstrak Etanol Daun Kamboja (Plumeria alba L) Terhadap Larva Artemia salina Leach dengan Metode Brine Shrimp Lethality Test (BST) (Thesis). Retrieved from http://eprints.undip.ac.id/23317/

Santoni, A., Darwis, D., and Syahri, S. (2013). Isolasi Antosianin dari Buah Pucuk Merah (syzygium campanulatum korth.) Serta Pengujian Antioksidan dan Aplikasi sebagai Pewarna Alami. Prosiding Semirata FMIPA Universitas Lampung.

Smith, H. (1975). Phytochrome and Photomor-phogenensis. McGraw-Hill Book Publishing Co. London.

Sutrisno, A. D. (1987). Pembuatan dan Peningkatan Kualitas Pewarna Merah Alami yang Dihasilkan oleh Monascus purpureus. Di dalam Pemanfaatan Ampas Tahu, Onggok dan Dedak untuk Produksi Pigmen Angkak oleh M. purpureus BC 88202 dengan Sistem Fermentasi Padat (Thesis). Retrieved from https://repository.ipb.ac.id/discover

Tedjautama, E., and Zubaidah, E. (2014). Increased Production of Red Pigment Angkak High Lovastatin Using Co-cultures of Monascus purpureus and Saccharomyces cerevisiae. Jurnal Pangan dan Agroindustri, 2(4), 78-88.

Triana, E. \& Nurhidayat, N. (2009). Pengaruh Saccharomyces cerevisiae terhadap Kadar Lovastatin dalam Angkak yang Dihasilkan dari Fermentasi Beras oleh Monascus purpureus JMBA. Berkala Peneliti Hayati, 14, 203-207. Retrieved from http://berkalahayati.org/index.php/jurnal/article/view/342

Yuliani, L. A. (2014). Pengaruh Konsentrasi Inokulum Monascus purpureus terhadap Produksi Pigmen pada Substrat Tepung Biji Nangka (Artocarpus heterophyllus) (Thesis). Retrieved from http://repository.upi.edu/3294/ 